\title{
DDIT4L Acute Lymphoblastic Leukemia
}

National Cancer Institute

\section{Source}

National Cancer Institute. DDIT 4L Acute Lymphoblastic Leukemia. NCI Thesaurus. Code C121975.

A gene expression subtype of acute lymphoblastic leukemia characterized by its expression level of the DDIT 4L gene. 